\title{
Structural Properties of Cement Stabilized Rammed Earth
}

\section{Jayasinghe and N. Kamaladasa}

Abstract: Earth is gradually gaining popularity as a structural material due to the desirable properties that can be obtained with various stabilization techniques. Cement stabilized rammed earth is one such application which can offer many advantages such as walls that will not need any mortar or plaster. The wider application of this material for walls of single and two storey houses will need strength and durability characteristics. The strength parameters relevant to compressive and flexural behaviours wore found using a detailed experimental study using wall panels. The durability characteristics were tested with panels soaked in water for 24 hours. The applications of above parameters for single and two storey houses were highlighted.

Keywords: Rammed earth, Structural properties

\section{Introduction}

The prevailing scarcity of conventional building material based on natural resources indicates the importance of developing alternative building materials. Thecontinuoususeofburntclaybricks or cement sand blocks as walling materials has led to the over exploitation of many natural resources with the associated environmental problems. The problems associated with excessive clay and sand mining can be highlighted as examples.

Due to the scarcity of conventional building mat: ials the awareness and interest on earth as - 1build ingmaterialhasgrown verymuchallover the world [1], [2], [3], [4]. Already, cement stabilized soil blocks have become a viable alternative to bricks and cement sand blocks in 5ı Lanka. Another alternative is cement stabilized rammed earth. This can offer many advantages in the light of the severe sand shortage prevailing in Sri Lanka since the walls will not have any mortarjoints. Since it can be constructed to give a reasonably straight and smooth surface, the need to apply plaster can be minimised. Thus, the consideration of rammed earth as an alternative walling material is extremely worthwhile. The wider applications willneed the strongl $h$ characteristics so that proper engineering design methods can be used with various applications. This paper highlights the findings of a detailed research carried out using wall panels made with different soils and cement contents tested for compressive and flexural properties. Further, rammed earth construction requiring unskilled labor comes as a solution to the scarcity and eventual high price of skilled masons, making it advantageous than any type of block construction.

\section{Objectives}

The main objective was to assess the following main design parameters.

a. Compressive strengths and associated parameters

b. Flexural strengths

c. Wet strengths and durability aspects

\section{Methodology}

In order to achieve the objectives, a number of wall panels were cast with different types of soils which were tested under compression and flexure. Wall panels immersed in water for 24 hours were also tested under compression. These results were compared with results obtained in various other countries to determine the suitability of laterite soils available in Sri Lanka for rammed earth construction. 


\section{Manufacturing process of rammed earth panels}

Rammed earth walls are formed by compacting the prepared soil inside a set of temporary forms. The soil is mixed with the chemical stabilizing agent (cement) [4], [5], [6] and a very small amount of water if the soil is too dry. The size of the moulds used in the experimental programme are $2^{\prime}-0^{\prime \prime}(0.6 \mathrm{~m}), 4^{\prime}-0^{\prime \prime}(1.2 \mathrm{~m})$ and $6^{\prime}-0^{\prime \prime}(1.8 \mathrm{~m})$ feetlong which can form $12^{\prime}-0^{\prime \prime}(3.6 \mathrm{~m}), 10^{\prime}-0^{\prime \prime}(3.0$ $\mathrm{m}), 8^{\prime}-0^{\prime \prime}(2.4 \mathrm{~m}), 6^{\prime}-0^{\prime \prime}(1.8 \mathrm{~m}), 4^{\prime}-0^{\prime \prime}(1.2 \mathrm{~m})$ and $2^{\prime}-0^{\prime \prime}(0.6 \mathrm{~m})$ long walls by combining two or three moulds. The soil is placed in layers of $100 \mathrm{~mm}$ to $150 \mathrm{~mm}$ thick and each layer is compacted with the manually operated hammer (Figure 1). Once the soil is compacted well, the formwork is moved upwards for the next lift of the wall.

The optimum water content is about $9.5-11.0 \%$ and the maximum dry density is about $20 \mathrm{kN} / \mathrm{m}^{3}$ for compaction levels. Mechanical stabilization by dynamic compaction seems to give better results as compared to static or vibro -static compaction [1]. The optimum moisture content (OMC) for rammed earth soils is critical in order to achieve maximum dry density through dynamic compaction, which will directly influence the strength and durability of the material [2].

The moisture content during the soil mixing stage was controlled by a simple test called drop test. A ball is made in the palm using a small sample of soil and then dropped on the floor from about 1.0 m height. If it breaks into 4 or 5 pieces, the moisture content is satisfactory. If it crumbles away, the soil is too dry or if it drops as one pat, it is too wet [7].

Not all soils are suitable for rammed earth construction. The Soil should be reasonably well graded between gravel to clay size particles. The main soil constituent forrammed earth is sand (40$70 \%$ ). Clay content from $10-20 \%$ is generally sufficient for binding as higher clay contents may result in excessive shrinkage [8]. The research carried out at the Department of Civil Engineering, University of Moratuwa in 1999 by Jayasinghe \& Perera [9] has shown that a clay content less than $30 \%$ is most suited for compressed earth blocks which are stabilized with cement. Therefore, in this study, three different laterite soil types were selected which can be identified as sandy, gravelly and clayey soils.
Unlike the other building materials, general suitability of soil composition for construction is not readily standardized because of its inherent natural variability. However, it is considered as an ideal replacement to reduce the environmental impacts, green house gas emissions and embodied energy [10]. Rammed earth technology is also suitable for soils with a high percentage of large grain size particles [1].

The three types of soils used for the experimental programme have material properties given in Table 1.

The results given in Table 1 were obtained from the sieve analysis. The silt and clay contents were considered together as this cannot be separated at the site conditions. At site, these proportions can be determined by conducting a jar test. As this technology will be popularized in the rural areas, where there can be difficulties in testing samples at laboratories, the jar test is an ideal measure to determine the soil type. In this simple test, a soil sample is placed in a bottle to about $1 /$ 3 the volume, the rest is filled up with water, shaken it well and left for about 24 hours. The composition of the soil sample can be seen as layers to approximately identify the constituent material [7].

Another important parameter that is of significant importance to strength and durability is cement. However, the cost of construction is very much affected by the cement content. Therefore, the optimum cement content should be determined to meet the strength requirements of single and two storey load bearing constructions.

Cement stabilization of soil increases the elastic modulus of the wall. It changed from $1.89 \mathrm{GPa}$ for unstabilised soil to $2.51 \mathrm{GPa}$ for $10 \%$ cement stabilized soil [1]. Since the wall has no joints, it can be adversely affected by shrinkage. The cement can control the shrinkage once the wall gains sufficient strength. It was found that shrinkage of cement stabilized soil increases rapidly during the first four days and at a later age the increase is very slow. Hence, curing during the first four days is very important in reducing drying shrinkage and cracking. Sand particles reduce the shrinkage as it opposes the shrinkage movement [1]. 


\section{Wall panel testing for compressive strength}

Wall panel dimensions were determined in such a way that the slenderness effects will not be predominant. The panels were constructed with three soil types mentioned in Section 4. A panel bring tested is shown in Figure 2. In addition to the compressive strength characteristics, the load deformation curve was also obtained. The load versus deflection values were used to find out the load deformation behaviour of rammed earth panels.

Two panels were constructed and tested for each parameter as stated in BS 5628: Part 1:1992. The ultimate load given in Table 2 is the average of the two values obtained for the identical panels. The summary of the results are given in Table 2. The average strength of wall panels is given in Table 3.

Thr characteristic compressive strength, $f_{k}$ of any masonry is determined by tests on wall specimens using the following equation (BS 5628: Part 1: 1992) [11]:

$\mathrm{P}_{1} . \mathrm{F}_{1 \mathrm{~B}} / \mathrm{A} \times \Psi_{\mathrm{m}} \Psi_{\mathrm{u}} / 1.2$

where,

$I$ is the mean of the maximum loads carried by the two test panels.

A is the cross sectional area of each panel $\Psi_{m}$ is the reduction factor for strength of mortar

$\Psi_{u}$ is the unit reduction factor for sample structural strength

The factor 1.2 is introduced to relate the tharacteristic value to the mean value. Both $\Psi_{\mathrm{m}}$ and $\Psi_{u}$ are taken as 1.0 since no mortar is used.

According to the results obtained for the three differentsoil types, sandy soil gave better results lor the characteristic strength. This confirms the findings made at the University of Bath, United Kingdom [8].

These strengths indicate that a characteristic cimpressive strength of $1.5 \mathrm{~N} / \mathrm{mm}^{2}$ could be used lor rammed earth walls. This is more than sufficient for single storey construction and hence economy can be achieved by using a wall Ihi kness of about $140-160 \mathrm{~mm}$. For two storey load bearing wall houses, wall thickness of 240 $\mathrm{mm}$ may be a possibility as recommended by Perera and Jayasinghe (2003) [9], with cement stabilized soil blocks. However, it is advisable to have more testing on thicker walls prior to actual adoption of this for two storey houses.

The weight of a panel varies from $190 \mathrm{~kg}$ to 220 $\mathrm{kg}$. The density of rammed earth is in the range of 1800 to $2000 \mathrm{~kg} / \mathrm{m}^{3}$.

Wet strength of wall panels was determined after soaking the panels in water for 24 hours. Wet strength results are given in Table 4 . For this, the complete panel was immersed in a water bath for 24 hours. Due to the difficulties of doing an immersed test, only the panels with gravely and clayey soils were used. These would be more susceptible to the strength decrease due to water.

Heathcote (1995) [3] has stated that the ratio of wet to dry strength be used as an indicator of the durability of earth wall components. The ratio of wet to dry strength of $0.33-0.5$ may be regarded as suitable depending on the severity of rainfall.

Table 4 shows that panels made with even gravelly or clayey soils can give a ratio more than 0.33 . Therefore, the strength of rammed earth walls under adverse conditions will be adequate.

According to the experimental results obtained for load deformation characteristics, rammed earth walls behave in a similar manner to the other masonry walls.

However, all three soil types gave load deformation characteristics with little warning before failure. As most of the panels did not show significant cracking before the ultimate crushing failure, a higher factor of safety is recommended in structural design of rammed earth walls. The availability of a compressive strength in excess of $1.5 \mathrm{~N} / \mathrm{mm}^{2}$ can give a very high factor of safety for single sotrey construction. New Zealand Standards [12] considers design strength of 0.5 $\mathrm{N} / \mathrm{mm}^{2}$ as adequate for single storey construction. This includes a factor of safety of about 5. Thus, rammed earth walls with commonly available laterite soils of low clay content can give a factor of safety close to 15 and hence can be used with confidence for single storey construction. 


\section{Flexural properties of rammed earth}

Flexural properties are of less significance than compressive strengths for load bearing masonry construction. New Zealand Standard [12] takes the characteristic bending strength equal to $10 \%$ of the characteristic compressive strength or about $0.1 \mathrm{~N} / \mathrm{mm}^{2}$ when no other data is available. Australian earth building hand book recommends ignoring any material strength in bending in the absence of test data [6].

In order to determine the flexural strength of rammed earth, a special test method was adopted. A wall panel was constructed over a concrete lintel of $75 \mathrm{~mm}$ thick and $160 \mathrm{~mm}$ wide. A rammed earth panel was constructed with a $725 \mathrm{~mm}$ height. On this, again a concrete lintel was placed. The length of the panel was 1900 $\mathrm{mm}$ and it was loaded to failureby applying loads as shown in Figure 3. A panel used for flexural testing is shown in Figure 4. The failure occurred with the formation of diagonal cracks which initiated at the supports. It should be noted that the concrete beams will be of very little influence to the failure load since the section predominately consists of cement stabilized rammed earth. Since the shear failure occurs due to direct tensile stresses induced in the wall, the failure stress can be used as an indication of tensile strength of the material. For the two panels tested, the shear stresses at first crack were $0.239 \mathrm{~N} / \mathrm{mm}^{2}$ and 0.31 $\mathrm{N} / \mathrm{mm}^{2}$ respectively. These give an average value of $0.275 \mathrm{~N} / \mathrm{mm}^{2}$. Therefore a value of $0.1 \mathrm{~N} / \mathrm{mm}^{2}$ recommended in New Zealand Standard [12] can be used for walls made with cement stabilized rammed laterite soils. This can be used to check the lateral stability of the walls such as free standing or simply supported at the top.

Vertical bending moment capacity of the wall is given by [6]:

$\mathrm{M}_{\mathrm{cy}}-\left(\begin{array}{ll}\mathrm{i}_{\mathrm{t}} & \mathrm{d}\end{array}\right) \times \mathrm{Z}$

Where, $f_{t}$ characteristic design bending strength of rammed earth which can be taken as $0.1 \mathrm{~N} /$ $\mathrm{mm}^{2}$.

$f_{d}$ design compressive stress at the cross section

$\mathrm{Z}$ - Section modulus of the cross section under consideration

\section{The uses of the strength properties}

The strength properties obtained from this detailed study can be used for a number of applications in the structural design of single and two sotrey houses. Some of them are highlighted below.

1. Design of load bearing walls subjected to vertical loads in single and two storey houses. This can be carried out using the design guidelines given in BS 5628: Part $1: 1992$, [11] and with a characteristic strength of $1.5 \mathrm{~N} / \mathrm{mm}^{2}$.

2. The flexural properties can be used to predict the lateral load carrying capacity of free standing walls as presented in $\mathrm{Cl}$. 36.4.3 of BS 5628: Part 1: 1992 [11].

3. The compressive strength can be used to determine the adequacy of internal return walls to carry both in-plane loads caused by lateral loads on outer walls and vertical loads that occur in two storey houses.

4. The shear capacity under flexural loads can be used to determine the reinforcement requirements for foundation strengthening needed in weak soil conditions [13].

It can be seen that the design parameters obtained on experimental basis will provide valuable design data that can be confidently used by design engineers for structural design purposes. This will assist in widening the applications of cement stabilized rammed earth and also making them safer.

\section{Conclusions}

The development of alternative building materials is of considerable importance in the context of various environmental problems associated with traditional building materials. Cement stabilized rammed earth is one such alternative. Whenever a new building material is introduced, determination of design parameters can enhance the range of applications.

As a result of the detailed experimental programme presented in this study, it is now possible to use rammed earth as a strong and durable material for wall construction. The design strength indicates that characteristic wall strengths in excess of $1.5 \mathrm{~N} / \mathrm{mm}^{2}$ can be obtained with cement stabilized rammed earth using 
laterite soils. The sandy laterite soils have shown the best behaviour. Thus, it is ideal for single stroey construction. It can become a potential building material even for the load bearing ground floor walls of two storey houses

Table 1: Particle size distribution of soil types

\begin{tabular}{|l|c|c|c|c|}
\hline \multicolumn{1}{|c|}{ Soil type } & $\begin{array}{c}\text { Particle size } \\
>19 \mathrm{~mm}\end{array}$ & $\begin{array}{c}\text { Gravel\% } \\
\text { content }\end{array}$ & $\begin{array}{c}\text { Sand \% } \\
\text { content }\end{array}$ & $\begin{array}{c}\text { Fines\% content } \\
\text { (clay and silt) }\end{array}$ \\
\hline Sandy & 4.3 & 32.2 & 59.4 & 8.4 \\
\hline Gravelly & 17.9 & 56 & 29.6 & 14.4 \\
\hline Clayey & 6.4 & 50.5 & 30.4 & 19.1 \\
\hline
\end{tabular}

Table 2: Results for the compression testing of panels

\begin{tabular}{|l|c|c|c|c|}
\hline Soil type & Cement \% & $\begin{array}{c}\text { Load at } \\
\text { first crack } \\
\text { (tonnes) }\end{array}$ & $\begin{array}{c}\text { Dimensions } \\
(\mathbf{m m x m m x m m})\end{array}$ & $\begin{array}{c}\text { Average load } \\
\text { (tonnes) }\end{array}$ \\
\hline Sandy & $6 \%$ & $*$ & $1045 \times 160 \times 633$ & 41.65 \\
\hline & $8 \%$ & $*$ & $1050 \times 155 \times 640$ & 58.20 \\
\hline & $10 \%$ & 45.0 & $1050 \times 160 \times 645$ & 61.25 \\
\hline Gravelly & $6 \%$ & $*$ & $1040 \times 160 \times 650$ & 33.70 \\
\hline & $8 \%$ & $*$ & $1020 \times 160 \times 630$ & 31.75 \\
\hline & $10 \%$ & 44.0 & $1035 \times 150 \times 640$ & 67.45 \\
\hline Clayey & $6 \%$ & $*$ & $1040 \times 163 \times 640$ & 31.10 \\
\hline & $8 \%$ & $*$ & $1030 \times 165 \times 630$ & 34.50 \\
\hline & $10 \%$ & 30.0 & $1050 \times 160 \times 698$ & 37.60 \\
\hline
\end{tabular}

*- no cracks formed before failure

Table 3: Average strength of wall panels

\begin{tabular}{|c|c|c|c|}
\hline \multicolumn{1}{|c|}{ Soil } & Cement & $\begin{array}{c}\text { Average strength } \\
\left(\mathbf{N} / \mathbf{m m}^{2}\right)\end{array}$ & $\mathbf{f}_{\mathbf{k}} \mathbf{( N / \mathbf { m m } ^ { 2 } )}$ \\
\hline Sandy & $6 \%$ & 2.47 & 2.06 \\
\hline & $8 \%$ & 3.525 & 2.94 \\
\hline & $10 \%$ & 3.71 & 3.09 \\
\hline Gravelly & $6 \%$ & 2.03 & 1.69 \\
\hline & $8 \%$ & 1.97 & 1.64 \\
\hline & $10 \%$ & 4.34 & 3.62 \\
\hline Clayey & $6 \%$ & 1.82 & 1.52 \\
\hline & $8 \%$ & 2.06 & 1.72 \\
\hline & $10 \%$ & 2.30 & 1.92 \\
\hline
\end{tabular}


Table 4: Wet strength results

\begin{tabular}{|c|c|c|c|c|c|c|}
\hline Soil type & Cement \% & $\begin{array}{c}\text { Load at } \\
\text { first crack }\end{array}$ & $\begin{array}{c}\text { Ult.load } \\
\text { (tonnes) }\end{array}$ & $\begin{array}{c}\text { Dimensions } \\
(\mathbf{m m} \times m m \times m m)\end{array}$ & $\begin{array}{c}\text { Weight } \\
(\mathbf{k g})\end{array}$ & $\begin{array}{c}\text { Strength } \\
\left(\mathbf{N} / \mathbf{m m}^{2}\right)\end{array}$ \\
\hline Gravelly & $6 \%$ & & $\mathbf{2 2 . 5}$ & $\mathbf{1 0 8 0} \times 160 \times 630$ & $\mathbf{2 1 8}$ & $\mathbf{1 . 3 0}$ \\
\hline Clay & $6 \%$ & $\mathbf{1 2}$ & $\mathbf{1 4}$ & $\mathbf{1 0 3 0} \times 160 \times 640$ & $\mathbf{2 1 6}$ & $\mathbf{0 . 8 5}$ \\
\hline
\end{tabular}

Table 5: Ratio of wet/ dry strength of rammed earth panels

\begin{tabular}{|l|c|c|c|c|}
\hline \multicolumn{1}{|c|}{ Soil type } & Cement \% & Dry strength & Wet strength & Ratio \\
\hline Gravelly & $6 \%$ & $\mathbf{2 . 0 3}$ & $\mathbf{1 . 3 0}$ & $\mathbf{0 . 6 4}$ \\
\hline Clay & $6 \%$ & $\mathbf{1 . 8 2}$ & $\mathbf{0 . 8 5}$ & $\mathbf{0 . 4 6}$ \\
\hline
\end{tabular}

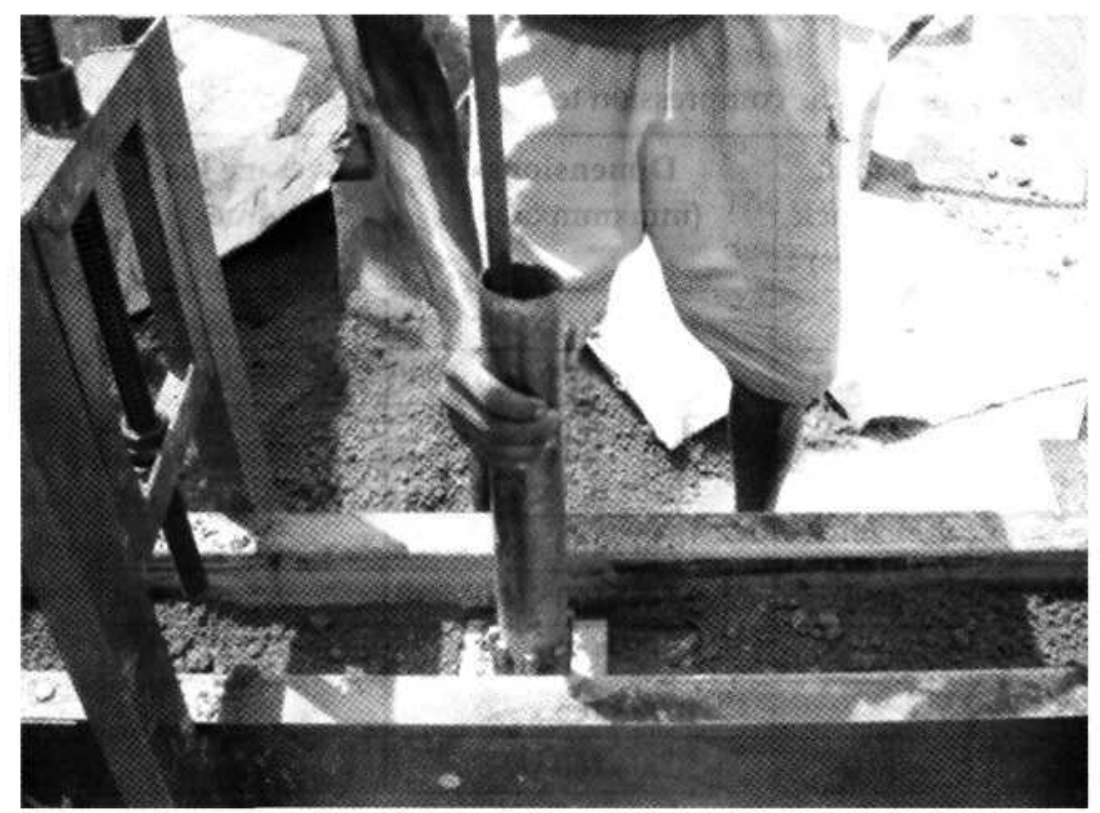

Figure 1: Moulds and hammer used to construct the rammed earth walls

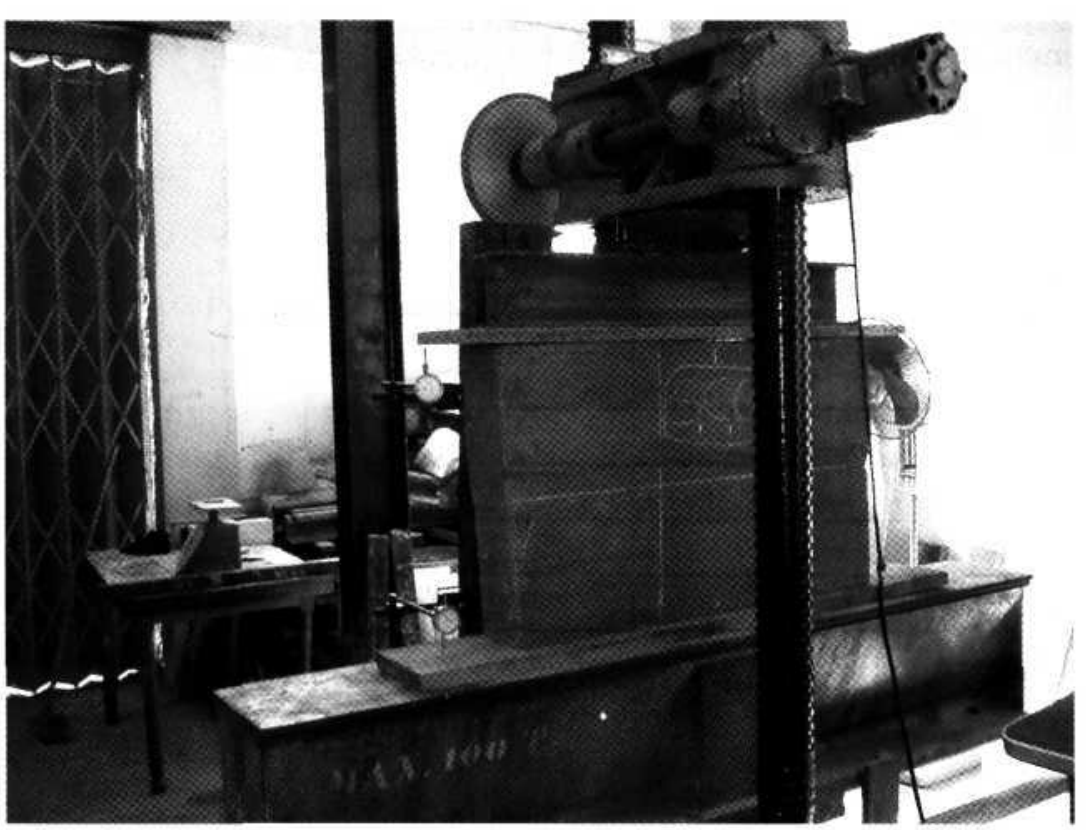

Figure 2: Panel being tested in the compression testing machine 


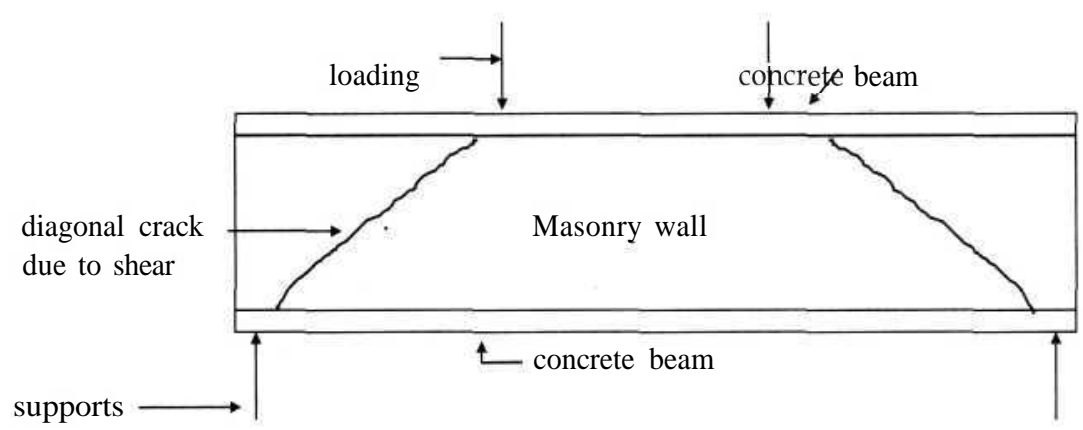

Figure 3: Testing of reinforced masonry beams in two point loading

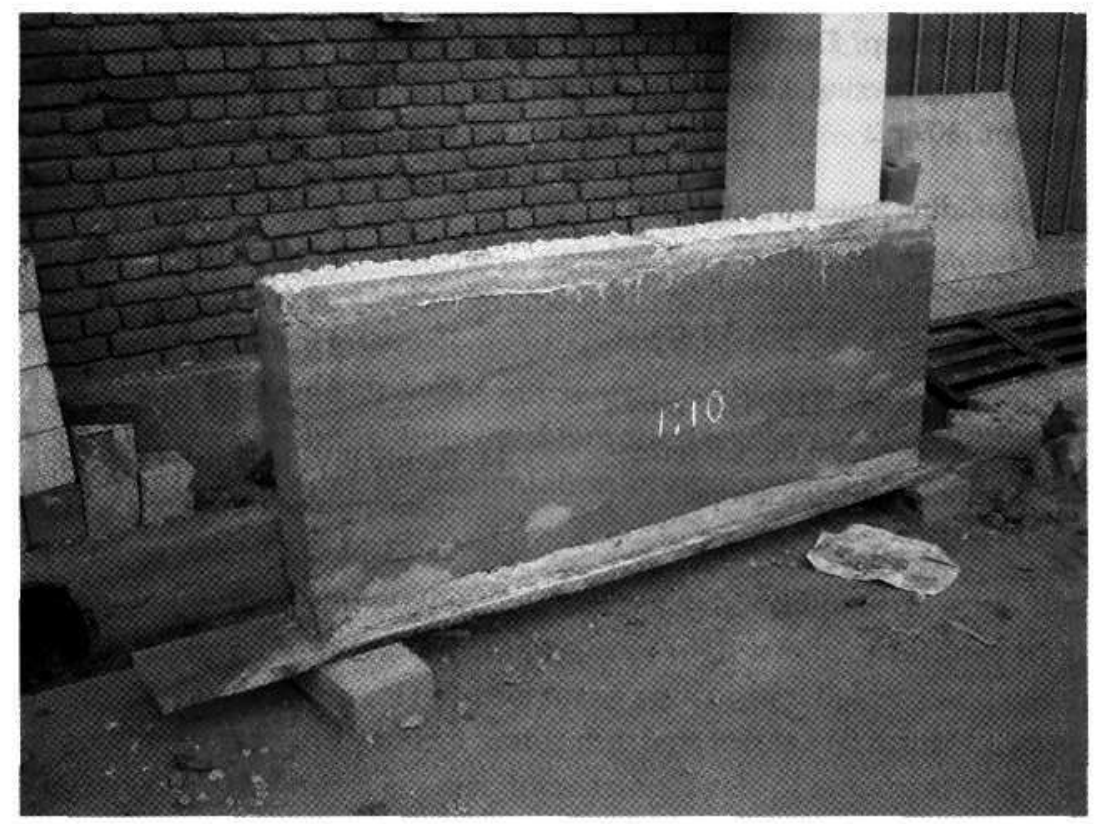

Figure 4: Wall panel used for flexural testing

which should be further investigated with additional laboratory experiments on the structural behaviour. The characteristic flexural strength obtained is more than $0.1 \mathrm{~N} / \mathrm{mm}^{2}$. Although it appears as a low value, this can give a significant lateral load carrying capacity for a thick wall. Since the weight of the structure will act as an advantage, it is possible to obtain suitable housing layouts that will have adequate vertical and lateral load resistances. Thus, rammed earth could be considered as a material of comparable strength to good quality bricks available in Sri Lanka.

\section{Acknowledgements}

The authors wish to thank the engineering staff of Center for Housing Planning and Building (CHPB) Mr. Chandradasa, Ms. Kandambi and Mr. Pushpakumara for their fullest cooperation in the experimental programme. The final year undergraduates, Messers ALP Silva, RS Mallawarachchi and KK Madurawala supported this experimental programme with much enthusiasm. The support given by the laboratory staff, Messers SPMadanayake, SLKapuruge, HP Nandaweera of The Department of Civil Engineering, University of Moratuwa for the testing programme is gratefully acknowledged. 


\section{References}

1. Bahar R., Benazzoung M., Kenai S., (2004), "Performance of compacted cement stabilized soil", Cement \& Concrete composites, 26, pp 811-820.

2. Hall M., Djerbib Y., (2004), "Rammed earth sample production: context, recommendations and consistency", Construction andBuilding Materials, 18, pp 281-286.

3. Heathcote K.A., (1995), "Durability of earth wall buildings", Construction andBuilding Materials, Vol: 9, No. 3, pp 185-189.

4. Walker P., Maniatidis V.,(2003), "A review of rammed earth construction", May 2003, Natural Building Technology group, Department of Architecture and Civil Engineering, University of Bath, United Kingdom, 109 p.

5. New Mexico Earthen building material code, (2003).

6. Standards Australia 2002, The Australian Building handbook, Standards Australia, Sydney, Australia.

7. Houben H. and Guillaud H., (1994), "Earth Construction", A comprehensive guide, CRTerre EAG, Intermediate Technology Publications.
8. www.bath.ac.uk. Developing rammed earth walling for UK housing construction.

9. Perera AADAJ, Jayasinghe C., (2003), "Strength characteristics and structural design methods for compressed earth block walls", Masonry International, Vol 16, No.1, January 2003, pp 34-38.

10. Morel JC, Meshah A, Oggero M, Walker P (2001), "Building houses with local material: means to drastically reduce the environmental impact of construction", Building and Environment, 361119 $-1126$

11. BS 5628: Part 1: 1992, Code of Practice for Use of Masonry, British Standards Institute, United Kingdom

12. NZS 4297: 1998, New Zealand Standards, Engineering design of earth buildings, Standard New Zealand, Wellington, New Zealand

13. Jayasinghe MTR, (1999), "Foundation improvement techniques for brick wall structures". Engineer, Journal of Institute of Engineers, Sri Lanka, Vol:xxx, No3, pp 41-50.

14. Reddy B.V., Jagadish J.S. (1989), "Properties of soil -cement block masonry", Masonry International, Vol: 3, No.2, October pp 80 -84. 